\title{
Understanding Failure in International Retailing: An Institutional Framework for Future Investigation
}

\author{
Alphonse Aklamanu \\ University of Vaasa, Vaasa, Finland
}

\begin{abstract}
The move from domestic market to one that includes major international firms is not proving an easy task for retailers. Whiles prior research acknowledged differences between country environments and stressed the importance of addressing these differences in order to avoid the dangers and failures inherent in internationalisation, there is still lack of suitable framework that captures the effects of the institutional environment on failure in international retailing. The purpose of this paper is to introduce institutional theory as a complementary framework to explain failure in international retailing and suggest propositions for further research. The paper seeks to answer the research question: What are the factors in the institutional environment of a host country that affect failure in international retailing? Consequently, the objective of this paper is threefold: (1) to introduce institutional theory as alternative theoretical framework to conceptualise failure in international retailing; (2) to identify institutional factors that exert pressures on the operational activities of international retailers in foreign markets and which leads to failure; (3) to provide some research propositions for further investigation. This paper offers several contributions. First, we extend current theories in international business, particularly, the literature on retail internationalisation and institutional theory by exploring pressures and difficulties that international retailers face in a new host institutional environment. Second, we identify a set of institutional factors that exert pressures on international retailers in foreign markets that lead to failure. Finally, with the institutional approach, this study fills the gap in earlier works by developing a complementary framework along with 11 propositions for future research. One major limitation of this paper is that it is conceptual; hence, further empirical analysis is needed to test the suggested propositions.
\end{abstract}

Keywords: failure, international retailing, institutional, retailing

\section{Introduction}

Retailing is rapidly becoming a global industry, and many of the world's well-known retailers already derive a large part of their sales from international operations. The last two decades have witness increase in retail foreign direct investment into a range of emerging markets across East Asia, Central and Eastern Europe, and Latin America, led by a small group of food and general merchandise retailers from Western Europe, and to a lesser extent, North America (Coe \& Wrigley, 2007, p. 341). On average, the top 250 retailers operated in 6.8 countries in 2007, up from 6.2 countries in 2006 and 5.9 in 2005 (Deloitte, 2009). In total, 21.3 percent of

Alphonse Aklamanu, Researcher/Ph.D. Candidate, Faculty of Business Studies, Department of Marketing, University of Vaasa, Finland.

Correspondence concerning this article should be addressed to Alphonse Aklamanu, University of Vaasa, Department of Marketing, Wolffintie 34, 65101 Vaasa, Finland. E-mail: alphonse.aklamanu@uwasa.fi. 
sales came from outside retailers' home countries (Deloitte, 2009).

The average top 250 European retailer had a presence in 14.9 countries in 2010, up from 11.1 countries in 2007, and over 40 percent of their total sales were from foreign operation in 2010, up from 35.1 percent in 2009 (Deloitte, 2012). French and German retailers are the most international in scope (Deloitte, 2012). The estimated global retail sale for the top 250 retailers in 2010 was US\$ 3.94 trillion (Deloitte, 2012). Many of the world's well-known retailers already derive a large part of their sales from international operations. For example, 44 percent of the sales space of Tesco in 2006 is outside the UK, mostly in Central Europe and East Asia (Dawson, 2007). Whilst showing an increasing interest for international expansion, many retailers consider the establishment of store networks in foreign markets difficult. This is due to the fact that retailers' expansion to foreign markets leads to the transfer of retail management technology or the establishment of international trading relationships across regulatory, economic, social, and cultural boundaries (Alexander, 1995).

Numerous examples of failed retail internationalization attempts are found in the literature. For example, Marks \& Spencer's (U.K.) withdrew from the Canadian and US market after several years of meagre performance (Burt, Mellahi, Jackson \& Sparks, 2002; Mellahi, Jackson, \& Sparks, 2002). Another example of unsuccessful internationalization attempt is Home Depot's recent withdrawal from the Chilean market (Bianchi \& Arnold, 2004), and Wal-Mart and Carrefour's failure in South Korea, Germany, and Japan (Aoyama, 2007; Christopherson, 2007; Gandolfi \& Strach, 2009; Kyung-Chool \& Soung-Hun, 2007). Similarly, Carrefour was very successful in Brazil, Argentina, and Taiwan, but failed in Germany. An examination of the literature on retail internationalisation highlights the influence of the institutional environment on retail failure in international retailing (Bianchi \& Arnold, 2004; Christopherson, 2007; Mellahi et al., 2002; O’Grady \& Lane, 1997).

Even though, prior research on retail internationalisation acknowledged differences among country environments and stressed the importance of addressing these differences in order to avoid the dangers and failures inherent internationalization (Alexander \& Myers, 2000; Bianchi \& Arnold, 2004; Bianchi \& Ostale, 2006; Burt et al., 2002; Burt, Dawson \& Sparks, 2003; Coe \& Wrigley, 2007; Vida \& Fairhurst, 1998; Vida, 2000), there is still a lack of a suitable framework that captures how the institutional environment impact on retail internationalisation failure. Burt et al. (2003) call for more work on understanding retail internationalisation failure phenomenon. Given the scarcity of suitable framework addressing retail internationalisation failure, this paper answers Burt et al.'s (2003) call by drawing on Scott $(1995,2001)$ three pillars of institutions (regulative, normative, cognitive) to develop a complementary framework to extend our understanding of retail internationalisation failure. As Burt et al. (2003) pointed out; if we are truly interested in comprehensive understanding of the retail internationalisation process, then we have to study failure as well as success. Therefore, this paper has three objectives: (1) to introduce institutional theory as a theoretical framework to conceptualise retail internationalisation failure; (2) to identify institutional factors that exert pressures on the operational activities of international retailers in foreign markets and which leads to failure; and (3) to provide some research propositions for further investigation. This paper therefore contributes to the literature in several ways: First we advance the literature on retail internationalisation by developing a complementary framework that enables the examination of failure at both macro and micro level. Second, we identify a set of institutional factors that influence failure in international retailing and developed a research model and propositions for future research. Finally, we extend the current theories in the field of international 
business, particularly, the literature on international retailing by accounting for pressures and difficulties that retailers face in a new institutional environment.

Utilising institutional perspective has several advantages for examining the effect of the institutional environment on failure in international retailing. First, institutional theory recognises that retailers are embedded in an institutional environment with specific institutional norms of retailing in which constituents make cultural and moral demands (Scott, 1987). Second, multinational retailers have direct contact with customers in the host countries, which makes international retailing highly culture specific (Vida, Reardon, \& Fairhust, 2000; Wrigley \& Currah, 2006). Third, in structural terms, multinational retailers must have physical presence in foreign countries. In other words, they have to invest in store network, supplier networks, and distribution and logistics infrastructure, with all the associated vulnerabilities that it brings (Wrigley \& Currah, 2006). Fourth, there is a considerable transfer of management expertise between different domestic retail systems, through international searches for new ideas and technologies (Alexander, 1997).

Finally, the institutional approach suggests that retail internationalisation success will increase when international retailer achieves legitimacy from employing practices and structures salient to norms of retailing of a country (Bianchi \& Arnold, 2004). Scholars from both the economic perspective (North, 1990) and the sociological perspective (DiMaggio \& Powell, 1983), agree that institutional forces affect organisational decision making from both macro and micro perspective (Huang \& Sternquist, 2007).

An important feature of this theory is an acknowledgement of the institutional environment, consisting of political, cognitive, and sociological elements like laws, rules, norms, cultural beliefs, and habits shared by relevant social actors (Bianchi \& Anold, 2004; Deligonul, Elg, Cavusgil, \& Ghauri, 2013; Handelman \& Arnold, 1999). The rest of the paper is organised as follows. First, we provide a brief review of the literature in institutional theory. Second, we provide a brief review of the literature on failure in international retailing. Third, we identify a set of institutional factors that influence failure in international retailing and develop a conceptual model along with propositions for future research. We then conclude with discussions and implications for theory and practice.

\section{Literature Review}

\section{Institutional Theory}

Institutional theory examines the role of social influence and pressures for social conformity in shaping organizational actions. Institutional theory emphasizes the role of social and cultural pressures imposed on organisations that influence organisational structures and practices (Scott, 1991). It views organisations as embedded in both its own internal institutional environment consisting of structures, standards, and practices established in the past (Meyer \& Rowan, 1977), and in an external environment consisting of other organisations such as customers, competitors, suppliers, and regulators (DiMaggio \& Powell, 1983; Granovertter, 1985). According to North (1990, p. 3), institutions are the "rules of the game in a society or, more formerly, are the humanly devised constraints that shape human interaction". DiMaggio and Powell (1983) argued that managerial decisions are strongly influenced by three institutional mechanisms - coercive, mimetic, and normative isomorphism that create and defuse a common set of norms, values, and rules to produce similar practices and structures across organisations that share common organisational field (DiMaggio \& Powell, 1983). Scott (1995) also proposed a similar framework but called them the three pillars of institutions: regulative, cognitive, and normative pillars. Scott (1995) defined institutions as "consisting of cognitive, 
normative, and regulative structures and activities that provide stability and meaning to social behaviour. Institutions are transported by various carriers- cultures, structures, and routines- and they operate at multiple levels of jurisdiction" (p. 33). Subsumed in both frameworks is the notion of legitimacy.

The regulative pillar of the institutional framework lays out the ground rules for doing business, reflecting the laws and regulations of a region or a country and the extent to which these rules are effectively monitored and enforced. Regulatory structures are relatively rational, negotiated arrangements to exchange problems that can change readily (North, 1990). The normative pillar consists of beliefs, values, and norms that define expected behaviour in a society. The cognitive pillar rests on the cognitive categories (e.g., schemata and stereotypes). The normative and cognitive institutional pillars are quite resilient and less subject to change than are the regulatory pillars (Scott, 2001). The cognitive institutional pillar is represented by the scripts, schemas, and taken-for-granted elements that influence individuals in a particular socio-cultural context. Under the institutional framework, the ultimate goal of the firm is survival, and therefore, organizations conform to institutional norms, not necessarily for reasons of efficiency, but rather to increase their legitimacy and survival capabilities (DiMaggio \& Powell, 1983; Meyer \& Rowan, 1977).

Thus, the social pressures are viewed to be equally important or even in some occasions that market competitive pressures in providing criteria for organizational survival (DiMaggio \& Powell, 1983). Under the label of "new institutionalism", there are differences between the economic version (North, 1990; Williamson, 1985) which focuses on efficiency, and the sociological version (DiMaggio \& Powell, 1991; Scott, 1995), which concentrates more on legitimacy delineating the theoretical boundaries of these perspectives beyond the scope of the present paper. This paper draws on the sociological perspective (Scott, 1995, 2001) in conceptualising the effect of the institutional environment on failure in international retailing. Although very little attention has been devoted to examining the role of the institutional environment in retail internationalization process, recently, a growing body of literature has started to apply institutional theory in the field of international retailing (Arnold, Handelman \& Tigert, 1996; Arnold, Kozinets, \& Handelman, 2001; Bianchi \& Arnold, 2004; Cao \& Pederzoli, 2013; Deligonul, Elg, Cavusgil, \& Ghauri, 2013; Duran \& Wrigley, 2009; Greve, 1998; Grewal \& Dharwadkar, 2002; Huang \& Sternquist, 2007; Pioch, Gerhard, Fernie, \& Arnol, 2009). Given that multinational retailers are embedded in multiple levels of institutional environments with different sources of authority (Wrigley \& Currah, 2006; Coe \& Lee, 2006), and different sets of legitimation requirements to which they must conform (Arnold, Handelman, \& Tigert, 1996), it will be helpful to use the institutional theory to analyse the institutional environment at multiple-levels, and to explore the ideas of failure in international retailing.

\section{Review of the Literature on Failure in Internationalisation Retailing}

Opinion on what constitute retail internationalisation failure differs among scholars. The definition of retail internationalisation failure is also diverse among scholars and problematic. Burt et al. (2003) pointed out that several terms and phrases are used in both the broad and emerging retail-specific literature (Alexander \& Quinn, 2002; Burt et al., 2002; Gielens \& Dekimpe, 2001), but rarely defined adequately. For example, according to Burt et al. (2003), Hollander (1970) used the term "de-internationalisation" but left it undefined. Since then, retail internationalisation failure in other studies have applied the term "de-internationalisation" (Benito \& Welch, 1997) or more recently as "divestment" (Alexander \& Quinn, 2002; Palmer, 2004, 2007; Cairns, Doherty, Alexander, \& Quinn, 2008), and other numerous terminologies such as "withdrawal, reduction 
in store holdings, exit, disengagement, liquidation, partial or total sales, spin-offs and sell-offs, management buyouts and equity carve-outs" have been used to describe aspects of the phenomenon (Burt et al., 2003, p. 357).

Although each term is totally different from others in its contextual sense, they often appear identical, thus causing even more confusion. Closure and divestment for instance as pointed out by Burt et al. (2003) have different implications and objectives depending on the firm's aim, that is, divestment as a corporate strategy rather than pure retreat, albeit their homogenous appearance. In addition, there exists an ambiguity with regard to defining what is being studied and what is the focus of the studies raises research questions that are particularly difficult to answer (Burt et al., 2003). Burt et al. (2002) explained that the majority of past retail internationalisation failure has been explored in conjunction with other studies, for example, with studies of retail structure at various scales, market exit at macro-economic level, and failures of small retailers, but failure was not the main focus of these studies (Burt et al., 2003). For instance, Alexander and Quinn (2002) identified reasons of failure within the framework of management literature, noting strategic issues as a reason for divestment. The authors argued the need to look at withdrawal issues not only on international retailer's capabilities but also within strategic issues. Palmer (2004) also adopted a similar approach and studied divestment within the context of corporate restructuring.

Consequently, previous studies (Burt et al., 2003; Mellahi et al., 2002) identified reasons for failure in internationalisation retailing under various perspectives, and the most notable influential work being Mellahi et al. (2002) and Burt et al. (2003). Mellahi et al. (2002) offered an explanation that combines two broad perspectives that highlight Marks and Spencer's internationalisation difficulties. Mellahi et al. (2002) examined the causes of organisational failure by drawing on two perspectives from the literature - industrial organisation (IO) and organisational studies (OS) literature to examine the failure of Marks \& Spencer. The IO literature attributes the causes of failure to the external environment, for example, turbulent demand structure as a result of brand switching, changes in consumer tastes and strategic competition due to rivalry among existing competitors or new entrants (Mellahi et al., 2002, p. 16). Organisational studies perspective on the other hand places more emphasis on internal factors associated with failure, for example, management's lack of vision and lack of will and ability to respond effectively and make necessary adjustments to reverse the downward spiral of decline triggered by external factors (Mellahi et al., 2002, p. 17). Applying these two perspectives, Mellahi et al. (2002) reached the conclusion that Marks \& Spencer's management inability and neglecting to adapt itself to the external retail environment were the most influential factors of its failure (see Table 1).

More recently, Burt et al. (2003) constructed a framework for failure of international retail operations categorised under four main factors, namely, market failure, competitive failure, operational failure, and business failure (see Table 2). Market failure refers to managerial perception of risk, cultural and psychic distance and competitive differences in a particular country. Competitive failure refers to retail sector formats and organisational type, choice of entry mode and age and size of the firm. Operational failure is attributed to length and time in the country, extent of international operations as indicated by the number of countries entered and number of formats, and the degree of adaptation made to customer interaction aspect of the format in a target market. Finally, business failure is attributed to managerial competency. Burt et al.'s (2003) categorisation is largely influenced by the works of Mellahi et al. (2002) and Benito (1997), but combines the necessary factors into a framework that examines both internal and external factors of retailer's failure. Burt et al. (2003, p. 358) defined failure as "unplanned under-performance by a firm that results in operational losses in 
some or all of the trading units in a foreign market leading to exit". Exit is the total withdrawal of the retailer from the foreign market, which may be achieved through the sale of assets, international store swaps, bankruptcy or other processes (Burt et al., 2003).

Table 1

Possible Causes of Corporate Failure

External circumstances (Industrial organisational perspective)

1. Turbulence in the specific market

2. Long-term decline in demand

3. Competition increase (new entrants)

4. Natural decline of business/market

5. Strong unexpected shocks to general market

6. Product/process innovation leading to obsolescence

7. Public policy and other interventions

Internal circumstances (Organisational studies perspective)

1. Commitment to pre-existing activities

2. Lack of perception of, and congruence with the market

3. Dismissal of new threats to the business

4. Management incapacity or incapability

5. Paralysis of decision-making

6. Structural obstacles to change

Note. Source: Extended from Mellahi et al. (2002) and Burt et al. (2003).

Table 2

Possible Causes of Failure in International Retailing

\begin{tabular}{|l|l|}
\hline A: & Market failure \\
\hline 1. & Failure is related to the degree of managerial perceived risk in any particular country \\
\hline 2. & $\begin{array}{l}\text { Failure is related to the extent and perception of cultural and psychic distance and competitive differences between host } \\
\text { and target countries. }\end{array}$ \\
\hline B: & Competitive failure \\
\hline 3. & Failure is related to the retail sector, format, and organisational type involved. \\
\hline 4. & Failure is related to entry mode. \\
\hline 5. & Failure is related to the stage of organisational development, normally viewed as the age and size of firm. \\
\hline C: & Organisational failure \\
\hline 6. & Failure is related to length of time in the country. \\
\hline 7. & $\begin{array}{l}\text { Failure is related to the extent of experience of the international operation as indicated by number of countries entered } \\
\text { and number of formats operated. }\end{array}$ \\
\hline 8. & Failure is related to the degree of adaptation made to the customer interaction aspects of the format in the target market. \\
\hline D: & Business failure \\
\hline 9. & $\begin{array}{l}\text { Failure is related to managerial competency of the firm in the home market and the management quality and } \\
\text { competency adopted in the target market. }\end{array}$ \\
\hline 10. & Failure is related to the degree to which the corporate culture is international. \\
\hline
\end{tabular}

Note. Source: Burt et al. (2003).

Although the work by Burt et al. $(2002,2003)$ helps in providing understanding of the influence of the external and internal environment on retail internationalisation failure, the authors failed to position their work within a particular institutional theoretical framework. For example, Mellahi et al. (2002) acknowledged that the identification of general themes pushed them in the direction of elaborating a general framework, thus their studies fall short of developing a comprehensive framework. Mellahi et al. (2002) indicated that there is an intricate web of internal and external factors that need to be more fully integrated into the study before such a 
framework would be possible.

We therefore address this gap by drawing on institutional theory (Scott, 1995, 2001) to explore the factors that influence failure in international retailing. Following Burt et al. (2003), we are not interested here in the case of market exit for more positive reasons, or for in other non-responses to failure. For the purpose of this paper, failure in international retailing is defined as:

Retailers' inability to cope and respond to institutional pressures in a foreign market which result in continuous operational losses in sales, profits, market share, store patronage, high supplier and employee turnover, and sanctions and punishments from the host government leading to exit from the foreign market.

\section{Failure in International Retailing: A Proposed Framework}

In this section, we describe the proposed framework that links the institutional environment to failure in international retailing. The conceptualisation of failure in international retailing under this institutional approach is the ability of international retailers to cope and respond to institutional pressures in a foreign market by adapting their retail structures, practices, and strategies to the salient regulatory, normative, and cognitive institutional norms of retailing in any country. This differs from market orientation approach where retailers focus mainly on consumers and competitors as the relevant social actors. Although consumers are usually key social actors for retailers in every country, from an institutional perspective, other social actors such as governments, suppliers, employees, distributors, local communities, investors/shareholders must also be considered for the retailers' survival and growth in a foreign market. Figure 1 depicts the relationship between the institutional environment and failure in international retailing.

First, we recognise that international retailers are embedded in both their own internal institutional environment consisting of structures, standards, and practices established in the past (Meyer \& Rowan, 1977), and in an external institutional environment consisting of other organizations such as suppliers, customers, competitors, and regulators (Coe and Wrigey 2007; DiMaggio \& Powell, 1983; Granovetter, 1985; Hess, 2004; Kostova, 1999; Wrigley \& Currah, 2006). Second consistent with previous research, especially that of institutional theory (Scott, 1995, 2001), we view the institutional environment as consisting of regulative, normative, and cognitive institutions. Third, we view the institutional environment at industry level as consisting of individual actors/constituents and organizations (e.g., governments, consumers, suppliers, competitors, regulatory agencies, professional associations, labour unions, general public, the media, environmental protection, or consumer activist organisations etc.) that interact with each other and with whom multinational retailers interlocks through complex webs of direct and indirect relationships.

In other words, we adopt the position that international retailers across countries belong to an institutional class or field that operates according to particular rule, logic, and norms that are subject to scrutiny and sanctions by governments and regulatory authorities and legitimating actors in case of deviating or violating the appropriate norms of retailing (Kostova \& Dacin, 2008). Under the regulative pillar, we argue that government pressure in the form of retail laws, rules, regulations, and standards designed to protect domestic retailers may affect failure. Under the normative pillar, we argue that the following factors exert pressures on the operations of international retailers in a foreign market which may lead to failure: (1) consumer pressure; (2) human resource pressure; (3) supplier/manufacturer pressure; (4) competition pressure; and (5) general public/media/community pressure. Under the cognitive pillar, we identify two factors that exert pressure on retailers in foreign markets which may lead to failure: (1) business system and ownership structure pressures; and (2) retail store structure pressure. 


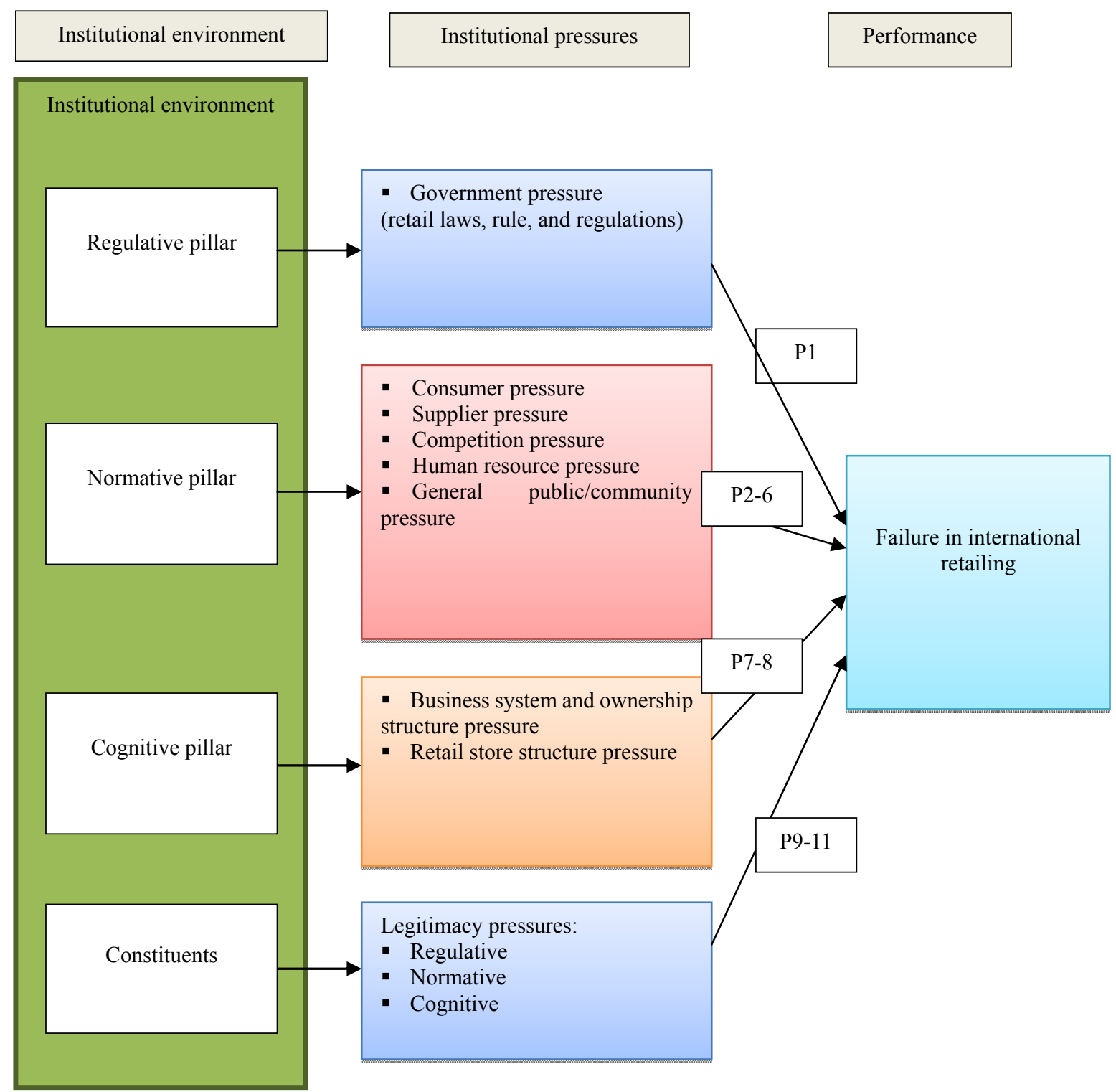

Figure 1. A framework of factors for failure in international retailing.

\section{Regulative pillar}

Government pressures. The regulative pillar of the institutional framework lays out the ground rules for doing business, reflecting the laws and regulations of a region or a country and the extent to which these rules are effectively monitored and enforced (Scott, 1995, 2001). In the context of international retailing, government pressures represent retail laws, rules, regulations, and labour standards enacted by the host government and local regulatory authorities to control retail foreign direct investment in a country. Many governments have strict regulation on retail format (e.g., Large Scale Retail Store Law (LSRSL) in Japan), pricing (e.g., Loi Gallant in France), store opening hours (e.g., Ladenschlussgesetz in Germany), store size requirement (e.g., Loi Raffarin in France), and land planning (e.g., PPG6 in England) (Huang \& Sternquist, 2007). Empirical evidence shows that retail regulations can restrict retailers' growth and expansion in foreign markets. For example, in South Korea, local governments restrict the entry of major foreign discount retailers into local market areas 
through change in regulation and taxation (Kyung-Chool \& Sough-Hun, 2007). The significant cost and difficulties in land acquisition in Japan contributed to derailing Carrefour's initial plans for rapid expansion into that market (Aoyama, 2007). For instance, according to Aoyama (2007), the country manager of Carrefour, Japan, claimed that Carrefour could have continued its operation in Japan if they had successfully launched 15-20 stores in the first five years. Consequently, due to restriction on large scale store in residential area, Carrefour could not rapidly open many new stores as planned in Japan and capture the market (Aoyama, 2007). The inability to secure suitable locations for their stores also placed Wal-Mart and Carrefour at great disadvantage against indigenous chains located in good traffic spots.

Similarly, in Germany, planning legislation prevents the developments of stores over $800 \mathrm{~m}^{2}\left(8,610 \mathrm{ft}^{2}\right)$ sales area in locations which are not designated for retailing (Guy, 2001). In effect, these restricts drastically limit Wal-Mart's freedom to develop new stores in their supercenter formats, hence, limiting the firms' growth in Germany (Christopherson, 2007; Guy, 2001). Growth in Germany has also been difficult for Wal-Mart due to strict regulation on pricing and promotion, and on store opening hours, as well as an inability to grow organically because of strict land use planning regulation (Fernie \& Arnold, 2002). In Germany, for example, loss leadership is forbidden and all customers must be given a refund if one customer discovers and claims a cheaper deal in a "refund the difference promotion" (Fernie \& Arnold, 2002). In Germany, Wal-Mart has encounter trouble with regulatory authorities and was fined $£ 308,000$ for selling goods below cost (Retail Week 2000, in Fernie \& Arnold, 2002). Unreasonable tax regulatory system was also found to have affected Wal-Mart and Carrefour's performance in South Korea. Carrefour and Wal-Mart have both exited the Japanese and German market. The above evidence suggests that countries with tight retail regulations including land and property law, competition laws, restriction on opening hours, zoning, building and outlet size codes, and so on can significantly limit the growth and performance of retailers. This leads to the following proposition:

Proposition 1: Failure in international retailing is related to strict retail laws, rules, regulations, and standards in any particular country.

\section{Normative Pillar}

Consumer pressures. Consumer pressures represent societal-based and economic-based norms of retailing in any country. Economic-based norms include: price, consumer taste and preferences, quality, product assortments, convenience, and service (Bianchi \& Arnold, 2004; Arnold et al., 1996). Societal-based norms include: norms of family, community, and nationalism. Owing to cultural and environmental differences, consumers in different countries may have different shopping experiences even in the same type of stores (Bianchi \& Arnold, 2004; Kim \& Jin, 2002). Research has shown that consumer taste and preferences and shopping habits of Japanese and South Koreans consumers are different from US consumers, and thus affected the performance of Mal-Mart and Carrefour in these markets (Aoyama, 2007; Choi, 2006; Coe \& Lee, 2006; Jin \& Kim, 2001; Kim, 2008).

For instance, the Japanese consumer has been referred to us the "most difficult consumer to strategize, as they require high quality on everything, and are knowledgeable about products, service, quality and prices from around the world... They are extremely brand-conscious, and demand brand products even on groceries" (Nikkei Business, 2005, p. 130, cited in Aoyama, 2007). In addition, research has shown that Japanese and South Korean consumers are sensitivity to price, seasonal changes in food items, love new products, and consider freshness and convenient shopping location as extremely important, are willing to make frequents 
visits to the supermarkets, corner shops, and traditional wet-markets to buy in small quantities (Choi, 2006; Coe \& Lee, 2006; Jin \& Kim, 2003; Kim, 2008). Kim (2008) noted that Korean local retailers accommodate this preference for food product freshness by transplanting the traditional outdoor market into a convenient indoors format hypermarkets. Thus, local retail chains have live sea food, local delicacies and extensively use localisation strategies that fit with Korean consumers taste and preferences.

In contrast, Wal-Mart's merchandising mix offers varied items from dry goods to electronic and clothing, which is viewed by Koreans to be more westernized than those of local chains. Similarly, local retailers in Japan accommodate consumer taste and preference for food product freshness by implementing a variety of labour-intensive strategies to increase customer appeal that went directly against Wal-Mart and Carrefour's low cost approach. For example, Aoyama (2007) stated that Japanese chains change merchandise in fresh seafood sections three times a day. In other words, local chains offer whole fish from nearby ocean in the morning, sliced into sashimi in the afternoon; and marinated and grilled fish in the evening. For special events, displays are converted overnight after store hours. However, all these practices are costly and therefore went against the low-cost, scale driven approach adopted by Wal-Mart and Carrefour. These strategies were practiced by Seiyu before Wal-Mart's takeover but were consequently eliminated as they created operational complexity for the distribution data structure developed and used by Wal-Mart (Aoyama, 2007). In Japan and South Korea, Wal-Mart and Carrefour also faced difficulties in matching their merchandize mix strategy, low price strategy, and global/standardisation strategy with differences in Japanese and South Korean consumers taste and preferences, and shopping habits.

For instance, Wal-Mart's trade-mark "every-day-low-price" (EDLP) strategy fails to appeal to Japanese and South Korean consumers who associate low price with low quality (Aoyama, 2007; Kyung-Chool \& Sough-Hun, 2007; Kim, 2008). As Kim (2008) pointed out, mismatched merchandising, assortment, and marketing that neglected local needs and context were other factors that contributed to Mal-Mart's failure in Korea. Similarly, Gandolf and Strach (2009) stated that product mix, promotion, and pricing strategies accounted for Wal-Mart's failure in South Korea because the firm failed to recognise that South Koreans have different consumer preferences than North Americans do. Likewise, Coe and Lee (2006) noted that Carrefour suffered from slow growth in the South Korean market because "mass supply at low price" was not sufficient to attract Korean customers. Similarly, Aoyama (2007) asserted that Wal-Mart and Carrefour's low-price approach and mass merchandising did not convert into revenue growth as cheap, to most Japanese also meant low-quality. These evidence leads to the following proposition:

Proposition 2: Failure in international retailing is related to consumer pressures regarding economic and societal-based norms of retailing (i.e., low price, assortment, quality, convenience, service, community etc.) in any particular country.

Human resource pressures. Human resource (HR) pressures represent human resource management policies and practices in any particular country. The retail sector is labour-intensive industry, hence, the inertial of institutional structures in a country is likely to hinder the application of new human resource practices such as recruitment, compensation, layoffs, and holiday entitlements whenever these practices are seriously at odds with existing legal rules and political conditions in a country. This is due to the fact that HR practices are subject to idiosyncratic sets of national regulations as well as sensitive to the scrutiny of labour unions whose strength and attitudes towards management vary (Gooderham, Nordhaug, \& Ringal, 1999). More precisely, there may be "a ceiling labour-standards effect" in which a transnational retailer finds it feasible to adapt its 
practices to suit countries where labour standards are lower than in its domestic market, but find it difficult to adapt and compete in business environments with higher labour standards than in its domestic market.

For example, in the case of Wal-Mart in Germany, Christopherson $(2006,2007)$ noted that because of strict planning regulations and labour laws, Wal-Mart was unable to practice the same wage practices as in the United States. An element of multinational retailer such as Wal-Mart and Carrefour's ability to keep profits high and prices low is the company's personnel policies which are often not compatible with unionisation requirement and labour management policies in many countries. For instance, studies of Wal-Mart's failure in Germany have focused on the firm's inability to implement the same labour management systems as in the US: involving limited welfare benefits, extremely rigorous supervision of employee work practices and so forth (Christopherson, 2007; Konzelmann, Wilkinson, Craypo, \& Aridi, 2005). As a result, Wal-Mart faced serious worker resistance, and was defeated by the German courts in the firm's attempt to implement its "ethical code of the employee" (an important tool of labour discipline in the US). Consequently, Wal-Mart also had significant difficulties in both the recruitment and retention of skilled workers (Christopherson, 2007).

Similarly in Japan, after Wal-Mart's take-over of Seiyu, restructuring resulted in involuntary early retirement of $25 \%$ of its full-time employees and raising the share of part-time employee to $85 \%$ (Aoyama, 2007). In addition, the introduction new IT-based supply chain system placed more workload on part-time employees. The CEO of Seiyu was also forced to resign without completing his term; still unspoken taboo in Japan's culture of lifetime employment. The lay-off reportedly had negative impact on the moral of Seiyu employee after Wal-Mart's take-over of Seiyu (Aoyama, 2007). According to Aoyama (2007), Seiyu's stock price, which doubled immediately following the announcement of Wal-Mart's take-over, fell to a third of its peak by mid-year 2005. Similarly, in South Korea, Carrefour adopted a more global human resource practice by assigning most senior managers and directors from the home office. However, this employment policy amplified the negative attitude of customers towards Carrefour as a foreign retailer (Coe \& Lee, 2006). Moreover, French managers and directors at Carrefour were found to be incapable of understanding and adopting South Korean labour practices (Coe \& Lee, 2006). Consequently, Carrefour experienced problems with human resource management and has been plagued with severe labour disputes with the labour unions which negatively affect employees and customers' perception of the company (Coe \& Lee, 2006). In other words, Carrefour failed to gain legitimacy from employees, unions, and consumers - critical social actors in retailing (Bianchi \& Arnold, 2004). Both Carrefour and Wal-Mart have eventually exit the Japanese and South Korean market, and their human resource policies and practices have been cited as a contributing factor to their failure in these markets (Coe \& Lee, 2006). This evidence leads the following proposition:

Proposition 3: Failure in international retailing is related to human resource policies and practices in any particular country.

Manufacturer and supplier pressures. Manufacturer and supplier pressures here represent manufacturer/suppliers-retailer relationship management practices in any particular country. Similar to lean production, retailing is not just about what happens internally in the firm, but also about the nature and content of relationships among firms - suppliers, manufacturers, retailers, and distributors in the host market (Christopherson, 2007). Ogbonna and Wilkinson (1988) argued that the nature of supplier-retailer relationship will play out differently depending on the relative concentration of both the retailing and manufacturing sectors that are concerned. The nature of power relations between retailers and suppliers may also vary between social and spatial contexts. Research shows that the power imbalance between manufacturers and retailers in Japan 
does complicate Japan's distribution sector for transnational retailers like Wal-Mart and Carrefour (Aoyama, 2007). Traditionally in Japan, manufacturers dictate the behaviour of retailers (Goldman, 1992). In other words, manufacturers determine the final store-front prices through Manufacturer's Suggested Retail Prices (MSRP) (Tsukiizumi, 2004, in Aoyama, 2007). For example, in Japan, most manufacturers refused to develop the factory-direct scheme with Carrefour and Wal-Mart at the expense of potentially alienating their long-term wholesalers and much larger domestic customers such as Aeon or Ito Yokado, the top two supermarkets in Japan (Aoyama, 2007). Similarly in South Korea, suppliers held large power over retailers (Coe \& Lee, 2006) and were unwilling to have open information exchange EDI system with Wal-Mart. They held seller power as they had the choice of supplying to other major local retailers, and also the fact that they have their own retail chains (Kim, 2008).

Large retailers like Wal-Mart and Carrefour cut cost by deploying the factory-direct to store model thereby eliminating wholesalers or middlemen in the supply chain. However, in Japan and South Korea, Wal-Mart and Carrefour were unable to implement the factory-direct business model and rip the benefit of scale. Thus, the inability to exercise network power over suppliers and the distribution channel made it difficult for Wal-Mart to transfer its lean retailing model which was its core competitive advantage in the U.S. market to countries like Germany, Japan, and South Korea (Aoyama, 2007; Coe \& Lee, 2006; Christopherson, 2007; Kim, 2008). Research have shown that Wal-Mart's difficulties with supplier network in Germany, Japan, and South Korea contributed to the firm's failure in these markets because it was unable to control the retail distribution system and its suppliers (Aoyama, 2007; Coe \& Lee, 2006; Kyung-Chool \& Soung-Hun, 2007). This leads to the following proposition:

Proposition 4: Failure in international retailing is related to power and concentration of manufacturers/suppliers in any particular country.

Competition pressures. Competition pressures here represent the maturity, concentration, and intensity of competition among indigenous retail chains in any particular country. In some countries, indigenous retailers have sometimes developed sufficiently protectable market scale (e.g., Shinsegae's E-Mart chain in South Korea; Aeon's Jusco in Japan; Sodimac in Chile) that they are well positioned to resist the entry of new foreign retailers. This is notably the case if international retailers face significant institutional, regulatory and operational/logistic barriers, or if the foreign retailer failed to invest sufficiently in the necessary territorial embeddedness (Coe \& Lee, 2007). In other words, to succeed in the foreign market, the international retailer has to some extent to localise its operationsin the foreign market (Coe \& Lee, 2006) and achieve organisational legitimacy in the host society/market (Bianchi \& Arnold, 2004; Coe \& Lee, 2006; Coe \& Wrigley, 2007). In this context, Bianchi and Mena (2004) and Bianchi and Ostale (2006) investigated in Chile the failure of Home Depot to establish themselves successfully in the market against consistent and fierce defence by the largest indigenous retail chains like D\&S and Cencosud in grocery retailing, and Sodimac in home improvement retail. Bianchi and Arnold (2004) and Bianchi and Ostale (2006) concluded that the failure of several international retailers in Chile, including Ahold, Carrefour, and Home Depot occurred in a context in which the leading indigenous retailers had the opportunity to anticipate and respond to the transnational retailers' source of competitive advantage.

More recently, in South Korea, the withdrawal of Carrefour and Wal-Mart from these markets have to be linked to fierce competition from indigenous retail chains, and failure to localise their operations (Coe \& Lee, 2006; Kim, 2008). Competitor pressure is also exerted by indigenous retail firms on foreign retail chains 
through pressure on indigenous suppliers not to sell to new foreign entrants. For instance, da Rocha and Dib (2002) noted that when Wal-Mart entered Brazil, indigenous retail chains put pressure on suppliers not to sell to Wal-Mart. Wal-Mart was perceived as selling below cost, which was considered by indigenous chains as unfair competition.

Consequently, some retailers were reported to have removed from their shelves leading brands from manufacturers that were seen as offering excessive advantage to Wal-Mart (da Rocha \& Dib, 2002). Similarly, Christopherson (2007) reported that Wal-Mart met fierce competition from German indigenous chains when it entered that market. Christopherson noted that the week that Wal-Mart opened in Berlin, the Aldi across the street from the new super store was selling the same loaf of bread that Wal-Mart was selling for \$1.13 US at \$0.34 US (Christopherson, 2007). Thus, in the German market, Wal-Mart met a consumer for whom "every-day-low-prices" meant little when a neighbourhood-based discounters such as Aldi, Netto, and Lidl can offer a much lower price (Christopherson, 2007). Apparently, Wal-Mart's competitive advantage of low price strategy was attacked by a set of domestic hard discounters also located and competing with one another in urban neighbourhoods. Carrefour eventually exited the German market.

Likewise, Larke (2003) noted that when Carrefour opened its first store in Tokyo suburb of Makuhari in December 2000, there was media frenzy, with 50,000 customers rushing to the store on the first two days of business. However domestic chains nearby, managed to undercut many of Carrefour's prices on the first day, effectively preventing customers from associating Carrefour with price competitiveness (Larke, 2003). On Carrefour's first anniversary in Japan, the store's atmosphere is described as "ghost town" in an early afternoon of the weekday, in spite of the ongoing anniversary sale (Asano, 2002, p. 36, cited in Aoyama, 2007). In the end, Carrefour could not sustain the competition and all eight brand-new stores, three in Tokyo region and five in the Osaka region, were sold to Aeon's Jusco stores, Japan's largest supermarket chain. Carrefour's estimated loss incurred in Japan was reported to be between $€ 200-300$ million (Nikkei Business, 2005, cited in Aoyama, 2007). These evidences lead to the following proposition:

Proposition 5: Failure in international retailing is related to the maturity, concentration, and intensity of competition by indigenous retail chains in a particular country.

Public/community/media pressures. Public/community pressures here represent constituents or social actor's perception and expectation about foreign retailers in any particular country. Transnational retailers because of their size and visible embedded investment in large workforce, real estate, suppliers, and distribution networks in the host country make them vulnerable to criticism and attack from the public, communities, and the media (Wrigley \& Currah, 2006). The public plays an important role in the legitimation process of foreign retailers, as this constituency controls critical resources on the demand side, such as local customers, and on the supply side such as local suppliers, local distributors, and the local labour force (Hybels, 1995). Given the impact of these social actors on organisational legitimacy, the public opinion in a country concerning the acceptance and approval of foreign retailers in general, and their actions and organisational practices in particular, constitute important factors in the legitimating process (Bianchi \& Arnold, 2004; Coe \& Lee, 2006). The local media assumes a monitoring role by reporting illegitimate actions by foreign retailers which lowers public endorsement (Aoyama, 2007; Coe \& Lee, 2006; Hybels, 1995). However, local media may also enhancement the legitimacy of foreign retailers operating in a foreign market by providing positive coverage about their actions and organisational practices (Elg, Ghauri, \& Tarnovskaya, 2008; Hybels, 1995).

It follows that foreign retailers have difficulty in understanding and accurately interpreting the host 
institutional legitimacy requirements of a country due to cross-national dissimilarities in regulative, normative, and cognitive norms of retailing, and so receive negative media coverage in foreign countries entered (Coe \& Lee, 2006; Larke, 2003). Public/community/media pressure is reflected in the number of negative media articles and press media about the transnational retailer in the media. Negative (unfavourable) media coverage is that information about the activities of the retailer which indicates that the operations/strategies and practices of the retailer are harmful to the societies or environments in which it operates. For example, in 2001, Wal-Mart Germany was the focus of increase attack from the press by unions, the employer or the trade association membership, and farmers. The German press refers to "the Wal-Mart Myth", critiquing the assumptions that Wal-Mart style logistics applications could transform German retailing (Christopherson, 2007).

Likewise, Larke (2003) stated that Wal-Mart's entry in Japan was met with negative press coverage and criticism of the firm's practices and strategies by the press and academic experts. According to Larke (2003) when Carrefour opened its first store in Japan in December 2000, perhaps partly because of its record breaking start, with 50,000 customers during the first two days, journalistic coverage has been disdainful and almost generally condemning, including a significant amount of outright propaganda. Empirical evidence shows that negative public opinion and the presentation of this opinion by the media hurts retailers' legitimacy in foreign markets (Christopherson, 2007; Coe \& Lee, 2006; Larke, 2003). For instance, Coe and Lee (2006) stated that negative attitude towards foreign discount chains in Korea is especially predominant outside main cities where many customers believe that foreign firms are not only driving out small and local stores, but are transferring the profits derived from the local economy to their overseas headquarters (Foreign Discount Chains, 2003, in Coe $\&$ Lee, 2006). The image of foreign retailers was also affected when the South Korean police found that Carrefour was smuggling out currency (Choi, 2003, in Coe \& Lee, 2006). This leads to the following proposition:

Proposition 6: Failure in international retailing is related to public/community/media perception and expectation of a foreign retailer in any particular country.

\section{Cognitive Pillar}

Business systems and ownership structure pressures. Business systems and ownership structure pressures here represent business systems and ownership structures in any particular country. Business systems play crucial role in explaining embeddedness of business organisations (Whitley, 1992). Whitley (1992) defined business system as a distinctive configuration of market hierarchy relations that become established and institutionalised in a specific social context. In the context of retailing, business system configuration may take varied forms including: state-owned enterprises, family-owned conglomerates, cooperatives, public listed companies (PLCs), private limited companies, and mom-and-pop shops etc.. Thus, a country's retail sector may be dominated by any of these business systems. For instance, Christopherson (2007) noted that German retail companies tend to be privately owned; relying on self-investment rather than public capital markets for investment, and are embedded in networks of neighbourhood establishments. Hung (2005) also pointed out that business systems in East Asia and Europe seem to differ significantly.

For instance, evidence shows that the South Korean business system and ownership structure are dominated by family conglomerates called (chaebols) such as Samsung, Hyundai, Daewoo, LG, and SK (Kim, 2008). This type of business systems therefore creates interconnected relationships that defines the ways that 
different groupings of social actors control economic activities and resources (Whitely, 1999, p. 32), social actors being the providers of capital, customers and suppliers, competitors, firms in different sectors and employers and different kinds of employees (Whitley, 1992). The extent to which firms are owned and controlled by families is also critical to the firms' network of relations with the business system. Hung (2005) noted that interconnectedness or embeddedness is gained through cross-equity holdings and long-term exchange relationships in the economy. Thus, the extent to which an international retailer is interconnected or embedded in a host institutional environment will be determined by the business systems and ownership structure it adopts in the host country. Different degrees of relationship define the extent to which firms are embedded in, and attend to their institutional environments (Oliver, 1996). Thus, transnational retailers expanding to foreign market can achieve embeddedness in the host institutional environment through mergers and acquisitions or entering into joint venture (JV) with a local partner.

Embeddedness in host institutional environment is crucial for the success of international retailers (Coe \& Lee, 2006). Kim (2008) pointed out that business systems and ownership structures such as family conglomerates (chaebol groups) based on their family and crony relationships form a powerful networking system that makes it difficult for even global retailer like Wal-Mart and Carrefour to break in. For instance, not realising such interconnectedness in business systems and ownership structures in South Korea, Wal-Mart and Carrefour first entered that market through wholly owned subsidiaries (WOS), and therefore isolated themselves against the local chaebols (Kim, 2008). Tesco on the other hand was fully aware of the Korean business system and ownership structures and decided to overcome the cognitive pressures of the local chaebol dominated business system by entering into a JV with a local partner, Samsung. Tesco is still in the market and performing well, while Wal-Mart and Carrefour have both exited that market.

Consequently, the JV provided Tesco with invaluable local partner necessary to gain territorial embeddedness or interconnectedness in the Korea business environment (Coe \& Lee, 2006). Working with a local partner is viewed by several commentators (Coe \& Wrigley, 2007; Hitoshi, 2003) as of crucial importance because of the market knowledge that is often transferred through these kinds of arrangements, accelerating the interconnecting or embedding process of the transnational retailer within local networks and improving its bargaining position with local governmental elites and suppliers (Currah \& Wrigley, 2004). Empirical evidence suggests that Wal-Mart and Carrefour failed in Germany, Japan, and South Korea because they failed to embed themselves in the host institutional environment by having relationships with local partners, government, suppliers, distributors, and trade unions (Coe \& Lee 2006; Christopherson, 2007). This leads to the following proposition:

Proposition 7: Failure in international retailing is related to business systems and ownership structure adopted in any particular country.

Retail store structure pressures. Retail store structure pressure here represents retail format structures in any particular country. Retail formats are culturally rooted in national institutions and thus vary across countries. In some countries, the retail sector is dominated by small corner shops, neighbourhood convenience shops, wet street markets, mom-n-pop shops, supermarkets, discount stores, hypermarkets etc.. In South Korea for example, with the development of the retail sector, indigenous discount stores accommodated Korean consumers' cultural taste and preference for food product freshness by transplanting the traditional outdoor market (wet market) into a convenient indoors format in hypermarket (Kim, 2008). Whereby, local retail chains have live sea food (e.g., fish and octopus in tank), local delicacies, and on-site packing services that replicate 
the features of traditional outdoor markets (Choi, 2003; Coe \& Lee, 2006; Kim, 2008).

Indigenous retail chains often pioneer new retail store format, which is cognitively rooted in the history and culture of that nation. Hence, foreign retailers who transfer their retail formats to foreign markets without any adaptation to match the host nation's culture often face significant problems regarding consumer acceptance or legitimacy. For instance, prior researchers have attributed Wal-Mart and Carrefour's failure in Japan and South Korea to their retail format (Aoyama, 2007; Coe \& Lee, 2006; Kim, 2008). Wal-Mart and Carrefour retain their "global" warehouse-style store layout, shelving, and décor in Japan and South Korea as in other markets (Aoyama, 2006; Coe \& Lee, 2006; Kim, 2008). However, regardless of retail formats, pleasant shopping environment, friendly service, and entertainment shopping atmosphere are critical to satisfy upscale tastes of local Japanese and Korean shoppers (Aoyama, 2007; Kim, 2008). Wal-Mart and Carrefour's neglect to adapt their store format to fit the consumer tastes and preference made it hard to compete with indigenous chains. This leads the following proposition:

Proposition 8: Failure in international retailing is related to cognitively accepted retail format in any particular country.

Legitimacy pressures. Legitimacy pressures here represent the need for a new retailer to be economically and socially accepted by social actors in any particular country. Organizational legitimacy has been defined as the acceptance of the organization by its environment (Dowling \& Pfeffer, 1975; Meyer \& Rowan, 1977). According to Scott (1995), organisations can acquire legitimacy by three forms: regulative legitimacy, normative legitimacy, and cognitive legitimacy. Based on institutional theory, social actors within the field of retailing in the host country will legitimise an international retailer based on how well the retail practices and structures conform to the institutional norms that are relevant for that social actor. Governmental bodies (the state) are the first group of actors that play a vital role in legitimation and through regulation try to ensure utility and responsibility of organizations (Hybels, 1995).

Regardless of whether regulatory institutions may facilitate or hinder retail internationalisation, one can say international retailers conform to regulatory restrictions, for example, by choosing certain retail formats, satisfying product quality standards, or unionization of workers for reasons of self-interest that include fear of sanctions and related costs of losing access to various resources necessary for survival and success. For example, adherence to retail laws, rules, regulations, and standards helps the retailer to secure resources, influence, and power (Meyer \& Rowan, 1977), and retailers that resist retail laws, rules, regulations, and standards are considered illegitimate. The resulting legal sanctions can for example, create additional administrative costs for firms and loss of access to necessary resources (DiMaggio \& Powell, 1983; Scott, 1995). Thus, an international retailer achieves regulative legitimacy by adhering to host retail laws, rules, regulations, and standards.

The public, as the second constituency, controls resources on the demand side as consumers, but perhaps even more importantly on the supply side as a source of labour, goods, and capital. The financial community provides very sophisticated evaluations of new and established organizations "based on collective assessments of future performance" (Hybels, 1995, p. 244) and thus plays a very important role in the legitimation process. Normative legitimacy is achieved by the transnational retailer through conformance to economic-based and societal-based norms of retailing including: low price, convenience, assortment, quality, family, excitement, community, and friendly service. Normative legitimacy is also achieved by the retailer conforming to host country retail management practices such as human resources practices (e.g., fair wages), supplier-retailer 
relationship management practices, and community norms such as giving to charity, and ethical social responsibility. Cognitive legitimacy is achieved by the retailer adopting ownership structures that facilitate embeddedness in host business and institutional networks, and adapting its retail formats to fit host cognitive retail structures. Thus, suppliers will legitimate a retailer based on fair or mutual beneficial relational exchanges.

Employees will legitimise a retailer that offers good working condition and observes fairness in hiring, training, and rewarding employees. Consumers will legitimise a retailer based on low price, wide assortment, service, quality, convenience, and retail concepts or formats. Communities will legitimate a retailer that is ethically and socially responsible. Because the institutional perspective views social actors as interconnected, hence, overall retailer legitimacy can be negatively affected if the retailer does not comply with the norms of retailing required by social actors in the host country (Bianchi \& Arnold 2004; Coe \& Lee, 2006). Legitimation theory posits that for any organisation to survive, it must be supported by its relevant constituents. Prior research shows that transnational retailers have failed in foreign markets because they fail to gain legitimacy from the relevant social actors (Bianchi \& Arnold, 2004). This leads to the following proposition:

Proposition 9: Failure in international retailing is related to retailers' inability to gain regulative legitimacy from social actors in any particular country.

Proposition 10: Failure in international retailing is related to retailers' inability to gain normative legitimacy from social actors in any particular country.

Proposition 11: Failure in international retailing is related to retailers' inability to gain cognitive legitimacy from social actors in any particular country.

\section{Discussions and Conclusions}

The purpose of this paper was to introduce institutional theory as a theoretical framework to conceptualise failure in international retailing. The paper also aims to identify institutional factors that exert pressures on the operational activities of international retailers in a host institutional environment. In addition, the paper aims to develop a framework of failure in international retailing and suggest research propositions for future investigation. As a first step towards understanding the effect of the institutional environment on failure in international retailing, we apply the institutional framework by Scott $(1995,2001)$ and explore the institutional environment at multiple levels: regulative, normative, and cognitive. We identified and described a set of institutional factors that exert pressures on the activities of international retailers which lead to failure in retailing.

We answer Burt et al. (2003) call for more work on understanding retail internationalisation failure phenomenon by providing a framework that enables the possible examination failure in international retailing. We have suggested a number of research propositions that provide some foundation for the consideration of failure in retail internationalisation. This propositions emphasis on concepts and processes rather than measurement, and we look forward to others having interest in this area to see if the concepts identified need refinement. We believe there are interrelationships between these factors we have identified and look forward to exploring these through qualitative and quantitative research. The major limitation of the papers is that it is a conceptual framework leading to the development of theoretical framework and propositions for further testing. Thus, empirical analysis is required to determine whether the theoretical connections between the formulated propositions can be established. In addition, this paper focuses on a single industry, retail, thus institutional 
pressures identified in this paper may be industry specific. Furthermore, although retailers are embedded in both its own internal institutional environment consisting of structures, standards, and practices established in the past, this paper focuses only on the external environment consisting of other organisations such as suppliers, customers, competitors, labour unions, governments/regulators and other social actors.

\section{References}

Ahlstrom, D., Bruton, G. D., \& Yeh, K. S. (2008). Private firms in China: Building legitimacy in an emerging economy. Journal of World Business, 43, 385-399.

Alexander, N. (1995). Internationalisation: Interpreting the motives. In P. J. McGoldrick, \& G. Davies (Eds.), International retailing: Trends and strategies (pp. 77-98). London: Pitman.

Alexander, N. (1997). International retailing. Oxford: Blackwell Business.

Alexander, N., \& Quinn, B. (2002). International retail divestment. International Journal of Retail \& Distribution Management, $30(2), 112-125$.

Aoyama, Y. (2007). Oligopoly and structural paradox of retail TNCs: An assessment of Carrefour and Wal-Mart in Japan. Journal of Economic Geography, 7, 471-490.

Arnold, S. J., Handelman, J., \& Tigert, D. J. (1996). Organisational legitimacy and retail store patronage. Journal of Business Research, 35, 229-239.

Arnold, S. J., Kozinets, R. V., \& Handelman, J. M. (2001). Hometown ideology and retailer legitimation: The institutional semiotics of Wal-Mart flyers. Journal of Retailing, 77(2), 243-271.

Basker, E. (2007). The causes and consequences of Wal-Mart's growth. Journal of Economic Perspective, 21, 177-198.

Benito, G., \& Welch, L. S. (1997). De-internationalisation. Management International Review, 2, 7-25.

Bianchi, C., \& Arnold, S. J. (2004). An institutional perspective on retail internationalisation success: Home Depot in Chile. International Review of Retail, Distribution and Consumer Research, 14(2), 149-169.

Bianchi, C., \& Mena, J. (2004). Defending the local market against foreign competitors: The example of Chilean retailers. International Journal of Retail \& Distribution Management, 32, 495.

Bianchi, C., \& Ostale, E. (2006). Lessons learned from unsuccessful internationalisation attempts: Examples of multinational retailers in Chile. Journal of Business Research, 59, 140-147.

Burt, S., Dawson, J., \& Sparks, L. (2003). Failure in international retailing: Research propositions. International Review of Retail, Distribution and Consumer Research, 13, 355-373.

Burt, S., Mellahi, K., Jackson, P., \& Sparks, L. (2002). Retail internationalization and retail failure: Issues from the case of Marks and Spencer'. International Review of Retail, Distribution and Consumer Research, 12, 191-219.

Cairns, P., Doherty, A. M., Alexanderc, N., \& Quinn, B. (2008). Understanding the international retail divestment process. Journal of Strategic Marketing, 16(2), 11-128.

Cao, L., \& Pederzoli, D. (2013). International retailers' strategic responses to institutional environment of emerging market: Multiple case studies in China. International Journal of Retail \& Distribution Management, 41(4), 289-310.

Child, J. (1972). Organisational structures, environmental and performance: The role of strategic choice. Sociology, 6, 1-22.

Choi, J., \& Park, J. (2006). Multichannel retailing in Korea: Effects of shopping orientation and information seeking patterns and channel choice behaviour. International Journal of Retail and Distribution Management, 34(8), 577-596.

Christopherson, S. (2007). Barriers to "US style" lean retailing: The case of Wal-Mart's failure in Germany. Journal of Economic Geography, 7, 451-469.

Clement, B. W., \& Douglas, T. J. (2005). Understanding strategic responses to institutional pressures. Journal of Business Research, 58, 1205-1213.

Coe, N. M., \& Lee, Y. S. (2006). The strategic localisation of transnational retailers: The case of Samsung-Tesco in South Korea. Economic Geography, 82(1), 61-68.

Coe, N. M., \& Wrigley, N. (2007). Host economy impacts of transnational retail: The research agenda. Journal of Economic Geography, 7, 341-371.

da Rocha, A., \& Dib, L. A. (2002). The entry of Wal-Mart in Brazil and the competitive responses of multinational and domestic firms. International Journal of Retail \& Distribution Management, 30(1), 61-73.

Dawson, J. (2007). Scoping and conceptualising retailer internationalisation. Journal of Economic Geography, 7, 373-397. 
Deligonul, S., Elg, U., Cavusgil, E., \& Ghauri, P. N. (2013). Developing strategic supplier networks: An institutional perspective. Journal of Business Research, 66(4), 506-515.

Deligonul, S., Elg, U., Cavusgil, E., \& Ghauri, P. N. (2013). Developing strategic supplier networks: An institutional perspective. Journal of Business Research, 66(4), 506-515.

Deloitte. (2009). Feeling the squeeze: Global powers of retailing. Retrieved from http://public.deloitte.com/media/0460/2009GlobalPowersofRetail_FINAL2.pdf

Deloitte. (2012). Switching channels: Global powers of retailing. Retrieved from http://www.deloitte.com/assets/Dcom-Portugal/Local\%20Assets/Documents/201201_GlobalPowersOfRetailing2012.pdf

DiMaggio, P. J., \& Powel, W. W. (1983). The iron cage revisited: Institutional isomorphism and collective reality in organisational field. American Sociological Review, 48, 147-160.

Dowling, J., \& Pfeffer, J. (1975). Organisational legitimacy: Social values and organisational behaviour. Pacific Sociological Review, 18, 122-135.

Dupuis, M., \& Prime, N. (1996). Business distance global retailing: A model for analysis of key success/failure factors. International Journal of Retail \& Distribution Management, 24(11), 30-38.

Duran, C., \& Wrigley, N. (2009). Institutional and economic determinants of transnational retailer expansion and performance: A comparative analysis of Wal-Mart and Carrefour. Environment and Planning A, 41, 1534-1555.

Dyer, G. (2007). China's labour debate spurs war of words for US interests. Financial Times.

Elg, U., Ghauri, P. N., \& Tarnovskaya, V. (2008). The role of networks and matching in market entry to emerging retail markets. International Marketing Review, 25(6), 774-699.

Etherington, L. D., \& Richardson, A. J. (1994). Institutional pressures on university education in Canada.. Contemporary Account Research, 10(S1), 141-162.

Fackler, M., Zimmerman, A., \& Lawrence, S. V. (2003). Store wars: Wal-Mart Takes on Japan. Far East Economic Review, 166, $38-41$.

Gandolfi, F., \& Strach, P. (2009). Retail internationalisation: Gaining insight from Wal-Mart experience in South Korea. Review of International Comparative Management, 10(1), 187-199.

Gielens, K., \& Dekimpe, M. G. (2001). Do international entry decisions of retail chains matter in the long run? International Journal of Research in Marketing, 18(3), 235-259.

Goldman, A. (1992). Japan distribution system: Institutional structures, internal political economy, and modernisation. Journal of Retailing, 67, 154-183.

Gooderham, P. N., Nordhaug, O., \& Ringdal, K. (1999). Institutional and rational determinants of organisational practices: Human resource management in European firms. Administrative Science Quarterly, 44(3), 507-531.

Goodstein, J. D. (1994). Institutional pressures and strategic responsiveness: Employer involvement in work-family issues. Academy of Management Journal, 37, 350-382.

Granovetter, M. (1985). Economic action and social structure: The problem of embeddedness. American Journal of Sociology, 91, 481-510.

Grewal, R., \& Dharwadkar, R. (2002). The role of the institutional environment in marketing channels. Journal of Marketing, 66, 82-97.

Handelman, J. M., \& Arnold, S. J. (1999). The role of marketing actions with a social dimension: Appeals to the institutional environment. Journal of Marketing, 63, 33-48.

Heider, R., \& Moeller, S. (2012). Outlet patronage in on-the-go consumption: An analysis of patronage preference drivers for convenience outlets versus traditional retail outlets. Journal of Retailing and Consumer Services, 19, 313-324.

Hitoshi, T. (2003). The development of foreign retailing in Taiwan: The impact of Carrefour. In J. A. Dawson, M. Mukoyama, S. Chul Choi, \& R. Larke (Eds.), The internationalisation of retailing in Asia (pp. 6-34). London: Routledge-Curzon.

Huang, Y., \& Sternquist, B. (2007). Retailers foreign market entry decisions: An institutional perspective. International Business Review, 16(5), 613-629.

Hughes, A. (1999). Constructing competitive spaces: On the corporate practice of British retailer-supplier relationships. Environmental Planning A, 31, 819-839.

Hung, S. C. (2005). The plurality of institutional embeddedness as a source of organisational attention differences. Journal of Business Research, 58, 1543-1551.

Hybels, R. C. (1995). On legitimacy, legitimation, and organizations: A critical review and integrative theoretical model. Academy of Management Journal (pp. 241-245). 
Ingram, P., \& Simons, T. (1995). Institutional and resource dependence determinants of responsiveness to work-family issues. Academy of Management Journal, 38, 1466-1482.

Jin, B., \& Kim, J. O. (2001). Discount store retailing in Korea: Shopping excitement, shoping motives, and store attributes. Journal of Global Marketing, 15(2), 81-107.

Kim, R. B. (2008). Wal-Mart Korea: Challenges of entering a foreign market. Journal of Asia-Pacific Business, 9(4), $344-357$.

Kim, S., \& Jin, B. (2002). Validating the retail service quality scale for US and Korean customers of discount stores: An exploratory study. Journal of Consumer Marketing, 16(2), 223-237.

Konzelmann, S. J., Wilkinson, F., Craypo, C., \& Aridi, R. (2005). The export of national varieties of capitalism: The case of Wal-Mart and IKEA. In N. Coe, \& N. Wrigley (Eds.), The globalizaton of retailing. Edward Elgar: Cheltenham.

Kostova, T., \& Dacin, M. T. (2008). Institutional theory in the study of multinational corporations: A critique and new direction. Academy of Management Review, 33(4), 994-1006.

Kyung-Chool, J., \& Soung-Hun, K. (2007). Factors causing the withdrawal of foreign retailer from the Korean retail market. Journal of Rural Development, 30(5), 61-81.

Larke, R. (2003). International retailing in Japan. In J. A. Dawson, M. Mukoyama, S. Chul Choi, \& R. Larke (Eds.), The internationalisation of retailing in Asia (pp. 6-34). London: Routledge-Curzon.

Mellahi, K., Jackson, P., \& Sparks, L. (2002). An exploratory study into failure in successful organisations: The case of Marks \& Spencer. British Journal of Management, 13, 15-29.

Meyer, J. W., \& Rowan, B. (1977). Institutionalized organisations: Formal structure as myth and ceremony. American Journal of Sociology, 83, 340-363.

Mezias, S. J. (1990). An institutional model of organizational practice: Financial reporting at the Fortune 200. Administrative Science Quarterly, 35, 431-457.

North, D. C. (1990). Institutions, institutional change and economic performance. Cambridge, U.K.: Cambridge University Press.

O'Grady, S., \& Lane, H. (1997). Culture: An unnoticed barrier to Canadian retail performance in the USA. Journal of Retail and Consumer Service, 4, 159-170.

Ogbonna, E., \& Wilkinson, B. (1998). Power relations in the UK grocery supply chain. Journal of Retailing and Consumer Services, 5, 77-86.

Oliver, C. (1991). Strategic responses to institutional processes. Academy of Management Review, 16, 145-179.

Palmer, M. (2004). International retail restructuring and divestment: The experience of Tesco. Journal of Marketing Management 20, 1075-1105.

Palmer, M., \& Quinn, B. (2007). The nature of international retail divestment: Insights from Ahold. International Marketing Review, 24(1), 26-45.

Park, C. (2005). Complaints of Asian shoppers towards global retailer: A content analysis of e-complaining to Carrefour Korea. Asia Pacific Journal of Marketing and Logistics, 17(3), 25-39.

Pfeffer, J., \& Salancik, G. R. (1978). The external control of organisations: A resource dependence perspective. New York: Harper \& Row.

Pioch, E., Gerhard, U., Fernie, J., \& Arnold, S. J. (2009). Consumer acceptance and market success: Wal-Mart in the UK and Germany. International Journal of Retail \& Distribution Management, 37(3), 205-225.

Powell, W. W. (1991). Expanding the scope of institutional analysis. In W. W. Powell, \& P. J. DiMaggio (Eds.), The new institutionalism in organisational analysis (pp. 183-203). Chicago: University of Chicago Press.

Scott, R. W. (1987). The adolescence of institutional theory. Administrative Quarterly Science, 32, 493-511.

Scott, R. W. (1991). Unpacking institutional arguments. In W. W. Powel, \& P. J. DiMaggio (Eds.), The new institutionalism in organizational analysis (pp. 164-182). Chicago: University of Chicago Press.

Scott, R. W., \& Meyer, J. W. (1983). The organization of societal sectors. In J. W. Meyer, \& W. R. Scott (Eds.), Organizational environments: Rituals and rationality (pp. 129-153). Beverly Hills, C.A.: Sage.

Scott, W. R. (1995). Institutions and organizations. Thousand Oaks, C.A.: Sage.

Scott, W. R. (2001). Institutions and organizations (2nd ed.). Thousand Oaks, California: Sage.

Tilly, C. (2007). Wal-Mart and its workers: Not the same all over the world. Connecticut Law Review, 39, 1805-1823.

Vida, I. (2000). An empirical inquiry into international expansion of US retailers. International Marketing Review, 17(4/5), 4534-4475.

Vida, I., \& Fairhurst, A. (1998). International expansion of retail firms: A theoretical approach for future investigations. Journal of Retailing and Consumer Services, 5(3), 143-151. 
Vida, I., Reardon, J., \& Fairhurst, A. (2000). Determinants of international retail involvement: The case of large U.S. retail chains. Journal of International Marketing, 8(4), 37-60.

Whitley, R. (1992). European business systems: Firms and markets in their national contexts. London: Sage.

Williamson, O. (1985). The economic institutions of capitalism. New York: Free Press.

Wrigley, N., \& Currah, A. (2006). Globalization and the "new e-economy": The organisational challenge of e-commerce for the retail NTCs. Geoforum, 37, 340-351.

Wrigley, N., Coe, N. M., \& Currah, A. D. (2005). Globalizing retailing: Conceptualizing the distribution-based TNC. Progress in Human Geography, 29(4), 437-457.

Zucker, L. G. (1991). The role of institutionalization in cultural persistence. In W. W. Powell, \& P. J. DiMaggio (Eds.), The new institutionalism in organisational analysis (pp. 83-107). Chicago: University of Chicago Press. 